\title{
Inhibition of sodium metabisulphite induced bronchoconstriction by frusemide in asthma: role of cyclooxygenase products
}

\author{
Brian J O'Connor, Peter J Barnes, K Fan Chung
}

\begin{abstract}
Background - Inhaled frusemide inhibits airway responses to sodium metabisulphite and other indirect bronchial challenges in asthma by undetermined mechanisms which may relate to its ability to stimulate prostaglandin release. Inhalation of sodium metabisulphite provokes indirect bronchoconstriction, possibly by activating sensory nerves. To investigate the role of cyclooxygenase products in the airway actions of frusemide and sodium metabisulphite, the effects of a potent cyclooxygenase inhibitor, flurbiprofen, alone and in combination with frusemide were investigated against airway responsiveness to sodium metabisulphite.
\end{abstract}

Methods - In a double blind double placebo controlled study, 12 mild asthmatic subjects attended on four occasions to undergo three inhalation challenges with sodium metabisulphite. A baseline challenge was performed one hour before oral intake of flurbiprofen $200 \mathrm{mg}$ or matched placebo, and two hours before inhalation of frusemide $40 \mathrm{mg}$ or matched placebo. A second challenge was performed immediately after inhalation of frusemide (two hours after flurbiprofen) with a further challenge three hours later. The log concentration provoking a $20 \%$ fall in $F_{1}\left(\log P_{20}\right)$ was used to assess airway responsiveness to sodium metabisulphite.

Results - Frusemide caused an immediate 1.9 doubling dose protection and a lesser 0.7 doubling dose protection at three hours. This protection was enhanced by flurbiprofen at both time points to 2.7 (early) and 1.9 (late) doubling doses. In addition, flurbiprofen alone significantly reduced airway responsiveness to sodium metabisulphite by 1.1 doubling doses at both two and five hours.

Conclusions - The generation of bronchoprotective prostaglandins is unlikely to underlie the inhibitory action of frusemide against airway responsiveness to sodium metabisulphite. Endogenous contractile prostaglandins within the airways may be involved in the bronchoconstrictor response to sodium metabisulphite.

(Thorax 1994;49:307-311)
Inhaled frusemide inhibits airway responses to sodium metabisulphite and other indirect bronchoconstrictor stimuli in asthma. ${ }^{1-5}$ The mechanism of the airway action of frusemide is unknown but appears to be independent of its major diuretic effect - inhibition of sodium chloride transport - as the related loop diuretic bumetanide has little or no effect on indirect bronchial challenge in asthma. ${ }^{2}$ Many of the effects of frusemide in the kidneys such as renal vasodilatation and natriuresis are dependent on prostaglandin synthesis, in particular $\mathrm{PGE}_{2} \cdot{ }^{67}$ One of the possible effects of frusemide in the airways may therefore be to stimulate the release of $\mathrm{PGE}_{2}$, one potential source of which is from airway epithelial cells. ${ }^{8}$ $\mathrm{PGE}_{2}$ is bronchoprotective and has been shown to attenuate asthmatic bronchoconstriction induced by sodium metabisulphite, ${ }^{9}$ exercise, fog, and inhaled allergen ${ }^{1011}$ challenges which are inhibited by frusemide. ${ }^{13-5}$

Inhalation of sodium metabisulphite causes bronchoconstriction in asthmatic subjects by indirect mechanisms which remain to be determined. ${ }^{1213}$ The observation that sodium metabisulphite is highly irritant to the airways and is a tussive agent suggests that it may act on airway sensory nerves. There is little direct evidence for this, however, as the effect of anticholinergic agents on sodium metabisulphite induced bronchoconstriction is variable; in one study the response was partially attenuated, ${ }^{14}$ but in two others there was little or no effect. ${ }^{1213}$ Airway responses to sodium metabisulphite are significantly reduced by nedocromil sodium ${ }^{1315}$ but are unaffected by terfenadine, the potent histamine $\mathrm{H}_{1}$ receptor antagonist, ${ }^{14}$ implying that the mechanism of action of sodium metabisulphite does not involve histamine release from airway mast cells. Whether endogenously released bronchoconstrictor prostaglandins mediate some of the effects of sodium metabisulphite is not known.

In the present study we examined two questions: (1) the possibility that the protective action of frusemide may involve generation of prostaglandin $E_{2}$ from the airways, and (2) the possibility that sodium metabisulphite may mediate its airway effects through release of bronchoconstrictor prostaglandins. We therefore evaluated the effect of a potent and specific cyclooxygenase inhibitor, flurbiprofen, on (1) the degree of protection afforded by frusemide against sodium metabisulphite induced bronchoconstriction, and (2) sodium metabisulphite induced bronchoconstriction alone. We also determined whether the duration of 
the protective effect of frusemide persisted for up to three hours.

\section{Methods}

SUBJECTS

Twelve non-smoking mild asthmatic subjects (table 1) gave informed consent to participate in the study which was approved by the Royal Brompton and National Heart Hospitals ethics committee. All were atopic as defined by a positive cutaneous response to intradermal challenge with common airborne allergens (Dermatophagoides pteronyssinus, mixed grass pollen, cat fur, and dog hair). None had suffered an exacerbation of wheeze nor a respiratory infection in the preceding six weeks. All were controlled on inhaled $\beta$ agonist therapy alone and had a baseline forced expiratory volume in one second $\left(\mathrm{FEV}_{1}\right)$ in excess of $80 \%$ of their predicted value. All had taken aspirin and other non-steroidal anti-inflammatory drugs without adverse reaction on a number of occasions but not within four weeks before participating in the study.

\section{STUDY DESIGN}

This was a balanced randomised double blind double placebo crossover study in which each subject attended on four different days, each separated by at least one week. Inhaled $\beta$ agonists and caffeinated beverages were withheld for at least eight hours before each visit. On each study day subjects underwent a baseline inhalation challenge with sodium metabisulphite. One hour later subjects took flurbiprofen $200 \mathrm{mg}$ or matched placebo in a single oral dose. After an interval of two hours each subject then inhaled either frusemide $40 \mathrm{mg}$ or placebo by continuous nebulisation for 15 minutes immediately before a second sodium metabisulphite challenge. A third sodium metabisulphite challenge was performed three hours after frusemide - that is, five hours after flurbiprofen. Thus, on the four visits subjects were challenged with sodium metabisulphite at three time points, once before and twice after treatment with either (1) placebos alone; (2) oral flurbiprofen $200 \mathrm{mg}$; (3) inhaled frusemide $40 \mathrm{mg}$; or (4) a combination of flurbiprofen and frusemide.

\section{Table 1 Characteristics of subjects taking part in study}

\begin{tabular}{lllll}
\hline $\begin{array}{l}\text { Subject } \\
\text { no. }\end{array}$ & $\begin{array}{l}\text { Age } \\
\text { (years) }\end{array}$ & Gender & $\begin{array}{l}F E V_{1} \\
(\% \text { predicted })\end{array}$ & $\begin{array}{l}\text { Baseline } P C_{20} \\
M B S(\mathrm{mg} / \mathrm{ml})\end{array}$ \\
\hline 1 & 36 & M & 108 & $20 \cdot 1$ \\
2 & 21 & F & 104 & $2 \cdot 0$ \\
3 & 25 & F & 83 & $9 \cdot 8$ \\
4 & 32 & M & 102 & $18 \cdot 1$ \\
5 & 29 & F & 93 & $9 \cdot 7$ \\
6 & 22 & M & 88 & $4 \cdot 4$ \\
7 & 26 & M & 81 & $5 \cdot 5$ \\
8 & 20 & M & 107 & $5 \cdot 7$ \\
9 & 34 & F & 91 & $10 \cdot 9$ \\
10 & 31 & F & 82 & $5 \cdot 8$ \\
11 & 27 & F & 90 & $8 \cdot 6$ \\
12 & 32 & F & 84 & $2 \cdot 1$ \\
\hline
\end{tabular}

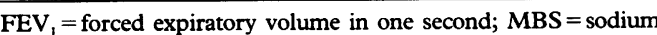
metabisulphite.
MATERIALS AND DRUG DELIVERY

On each study day fresh solutions of sodium metabisulphite (Sigma, UK) were made up to produce a range of concentrations in $0.9 \%$ saline of $0 \cdot 3-80 \mathrm{mg} / \mathrm{ml}$. Each solution was administered from a nebuliser attached to a breath activated dosimeter (Mefar, Brescia, Italy). The nebuliser delivered particles with an aerodynamic mass median diameter of 3.5$4 \mu \mathrm{m}$ at an output of $10 \mu \mathrm{l} / \mathrm{breath}$. The dosimeter was set to nebulise for one second with a pause time of eight seconds at a pressure of 22 psi.

Flurbiprofen (Boots, Nottingham, UK) or matched placebo was administered as four $50 \mathrm{mg}$ capsules. Frusemide $(10 \mathrm{mg} / \mathrm{ml}$ in distilled water containing sodium hydroxide $1.2 \mathrm{mg} / \mathrm{ml}$, pH 5.3, osmolarity $209 \mathrm{mosmol}$ ) (Antigen, Roscrea, Ireland) or matched placebo (pH 5.6, osmolarity 225 mosmol) was delivered by continuous nebulisation from an Acorn Jet nebuliser (Medic-aid, Sussex, UK) with a calibrated output of $0.25 \mathrm{ml} / \mathrm{min}$ at a driving pressure of $6 \mathrm{l} / \mathrm{min}$. The nebuliser delivered an aerosol with aerodynamic diameter of $3.5 \mu \mathrm{m}$ at this flow rate as measured by a laser particle sizer (Model $2600 \mathrm{~d}$, Malvern, Worcestershire, UK).

\section{BRONCHIAL PROVOCATION AND MEASUREMENT} OF PULMONARY FUNCTION

Pulmonary function was measured as $\mathrm{FEV}_{1}$ with a dry wedge spirometer (Vitalograph, Buckinghamshire, UK). A standard challenge protocol was used for all provocation tests. On arrival in the laboratory each subject rested quietly for 15 minutes before three measurements of $\mathrm{FEV}_{1}$ taken at one minute intervals. Subjects then inhaled five breaths of saline control by inspiring slowly from functional residual capacity to total lung capacity over three seconds and then breath holding for five seconds. $\mathrm{FEV}_{1}$ was measured two minutes after inhalation of saline. Unless a fall in $\mathrm{FEV}_{\text {, }}$ of greater than $10 \%$ was seen, subjects inhaled five breaths of doubling concentrations of sodium metabisulphite starting at $0.3 \mathrm{mg} / \mathrm{ml}$ until a greater than $20 \%$ fall in FEV from the post saline value was achieved. A log doseresponse curve was constructed and the provocative concentration causing a $20 \%$ fall in $\mathrm{FEV}_{1}$ was calculated by linear interpolation and expressed in logarithmic terms $\left(\log \mathrm{PC}_{20}\right)$. Challenges were performed at the same time of the day for each individual.

\section{DATA ANALYSIS}

Log $\mathrm{PC}_{20}$ values for sodium metabisulphite before and at both time points after active and placebo treatments were compared using analysis of variance for multiple comparisons and the change assessed by the least significant difference test. The protective effect of each treatment on responses to sodium metabisulphite at both time points was calculated by measuring the change in $\log \mathrm{PC}_{20}$ from the baseline after all active and placebo treatments 
Table 2 Mean ( $S E$ ) forced expiratory volume in one second ( $F E V_{1}$, litres) before (pre) and at both time points, early (post 1) and late (post 2), after treatment

\begin{tabular}{llll}
\hline & Pre & Post 1 & Post 2 \\
\hline Placebo & $3.28(0.30)$ & $3.23(0.29)$ & $3.28(0.29)$ \\
$\begin{array}{l}\text { Frusemide } \\
\text { Flurbiprofen }\end{array}$ & $3.34(0.28)$ & $3.28(0.29)$ & $3.40(0.29)$ \\
$\begin{array}{l}\text { Frusemide }+ \\
\text { flurbiprofen }\end{array}$ & $3.25(0.27)$ & $3.19(0.28)$ & $3.24(0.30)$ \\
\hline
\end{tabular}

and expressed in terms of doubling doses using the formula:

(post - pre) $\log \mathrm{PC}_{20}$ active - (post - pre) log $\mathrm{PC}_{20}$ placebo/log 2

Baseline spirometric results before and at both time points after each treatment were also compared using analysis of variance for multiple comparisons.

Results are expressed as mean (SE). A p value of $<0.05$ was regarded as significant.

\section{Results}

Baseline spirometric values were unchanged throughout all treatment periods. Neither flurbiprofen nor frusemide, alone or in combination, caused any significant bronchodilatation (table 2). No side effects were reported by any subject after any of the treatment periods.

Baseline $\log \mathrm{PC}_{20}$ sodium metabisulphite was similar on all four study days (figure). On the placebo limb, log $\mathrm{PC}_{20}$ responses were unchanged throughout the day $(0.84(0.10)$ before, and $0.83(0.11)$ and $0.84(0.09)$ at both time points after placebo) (figure).

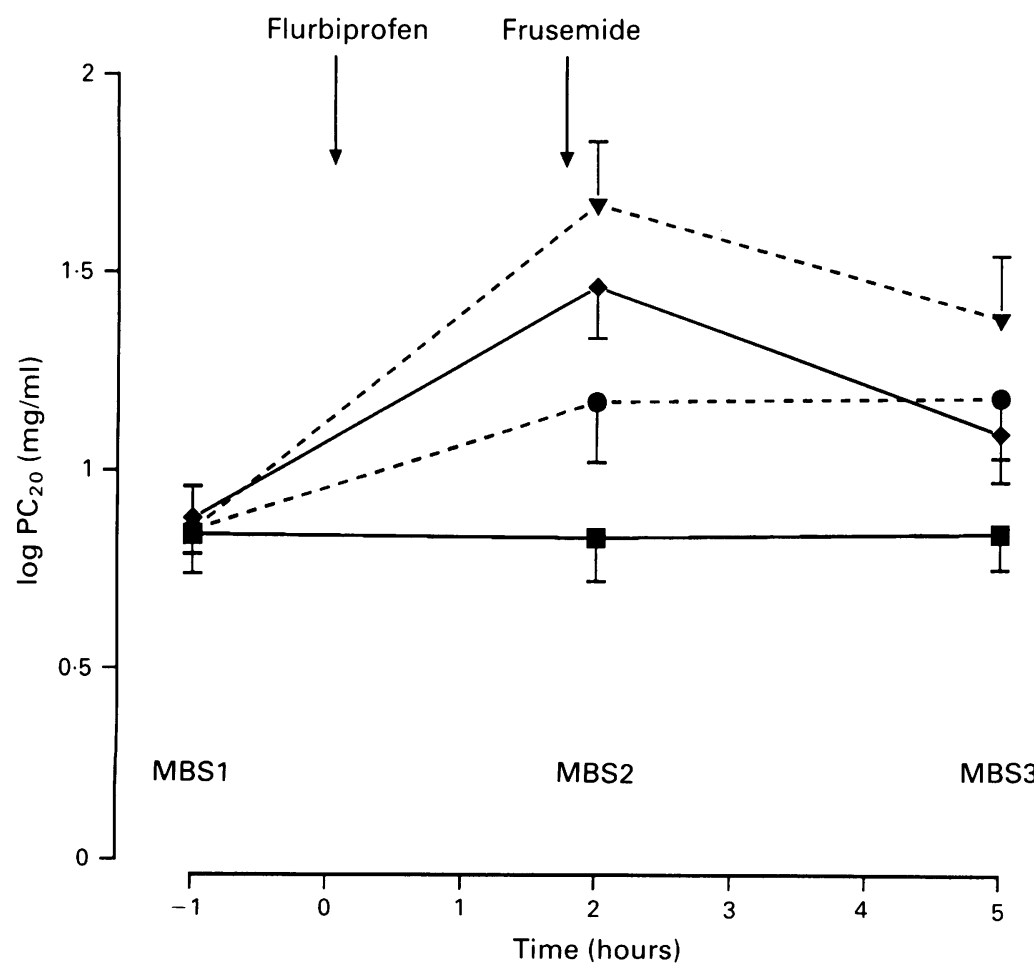

Airway responses ( $\left.\log P C_{20}, \mathrm{mg} / \mathrm{ml}\right)$ to sodium metabisulphite (MBS) before $(M B S 1)$ and at both time points (MBS2, MBS3) after flurbiprofen and frusemide. - placebo; frusemide + flurbiprofen.
FRUSEMIDE $v$ SODIUM METABISULPHITE

Inhalation of frusemide alone significantly reduced responsiveness to sodium metabisulphite at both time points $\left(\log \mathrm{PC}_{20} 0.88(0.09)\right.$ before, $1.46(0.13)$ immediately after, and 1.09 $(0 \cdot 12)$ three hours after treatment) (figure). Thus frusemide displaced the sodium metabisulphite dose-response curve to the right by 1.9 doubling doses immediately $(p<0.01)$ and by 0.7 doubling doses at three hours $(\mathrm{p}<0.05)$.

\section{FLURBIPROFEN $v$ SODIUM METABISULPHITE}

Flurbiprofen alone significantly attenuated the constrictor response to sodium metabisulphite $\left(\log \mathrm{PC}_{20} 0.85(0 \cdot 11)\right.$ before, $1 \cdot 17(0 \cdot 15)$ at two hours, and $1 \cdot 18(0 \cdot 15)$ at five hours after treatment) (figure). Flurbiprofen therefore displaced the dose-response curve of sodium metabisulphite to the right by $1 \cdot 1$ doubling doses at both time points compared with placebo $(\mathrm{p}<0.01)$.

\section{FLURBIPROFEN AND FRUSEMIDE IN}

\section{COMBINATION $v$ SODIUM METABISULPHITE}

\section{CHALLENGE}

Combined treatment with flurbiprofen and frusemide had a greater effect on $\log \mathrm{PC}_{20}$ sodium metabisulphite than either treatment alone $(0.85(0.11)$ before treatment, $1.67(0.16)$ two hours after flurbiprofen and five minutes after frusemide, $1.38(0 \cdot 16)$ five hours after flurbiprofen and three hours after frusemide) (figure). The combination therapy therefore displaced the sodium metabisulphite doseresponse curve to the right by 2.7 doubling doses at the early time point $(\mathrm{p}<0.001)$ and by 1.9 doubling doses at the later time point $(p<0.001)$ when compared with placebo. This shift in the dose-response curve was significantly greater than after either agent alone $(\mathrm{p}<0.01)$.

\section{Discussion}

This study confirms that inhaled frusemide inhibits sodium metabisulphite induced bronchoconstriction ${ }^{1}$ and that the duration of this inhibition can last for up to three hours. This protection is significantly enhanced by a single oral dose of flurbiprofen, increasing the early and late effects of frusemide from 1.9 to 2.7 and from 0.7 to 1.9 doubling doses respectively. Furthermore, flurbiprofen alone reduced the constrictor response to sodium metabisulphite by $1 \cdot 1$ doubling doses at both two and five hours after treatment.

Our results show that the release of prostaglandins such as $\mathrm{PGE}_{2}$ is unlikely to mediate the protective effect of frusemide against sodium metabisulphite induced bronchoconstriction. Flurbiprofen did not inhibit but, rather, enhanced the actions of frusemide. The interpretation of this enhancement is complicated by the observation that flurbiprofen alone significantly protected against sodium metabisulphite challenge. This protection of $1 \cdot 1$ doubling doses at both time points, when added to the 1.9 (early) and 0.7 (late) 
doubling dose protection of frusemide alone, is equivalent to the protection of both agents in combination. The protection observed with the combination of flurbiprofen and frusemide is therefore likely to be additive, implying that the mechanism of protection of frusemide against sodium metabisulphite is unaffected by cyclooxygenase inhibition.

The lack of significant involvement of bronchoprotective prostaglandins in the airway actions of frusemide is supported by the recent observation that aerosolised lysineaspirin did not influence the inhibitory effect of frusemide against exercise induced asthma. ${ }^{16}$ In a recent study of similar design, however, another cyclooxygenase inhibitor (indomethacin, $50 \mathrm{mg}$ three times daily for three days) reduced the protective effect of frusemide against exercise induced asthma in the absence of an effect of indomethacin alone, implying that during exercise frusemide may generate bronchoprotective prostaglandins such as $\mathrm{PGE}_{2}$ and $\mathrm{PGI}_{2}$ within the airways. ${ }^{17} \mathrm{~A}$ differential effect of these prostaglandins on different bronchial challenges cannot explain the difference in the two studies because both $\mathrm{PGE}_{2}$ and $\mathrm{PGI}_{2}$ protect against bronchoconstriction induced by sodium metabisulphite and exercise. ${ }^{911}$ The disparity between these data and the results of our recent study may be a result of the differences in the properties of flurbiprofen and indomethacin. Flurbiprofen inhibits the immediate bronchoconstrictor response to allergen, ${ }^{18}$ exercise, ${ }^{19}$ and adenosine ${ }^{20}$ whereas indomethacin has little effect on these challenges. ${ }^{172122}$ Although we cannot account for the contrasting effects of these two agents on asthmatic airways, it is possible that flurbiprofen is a more potent and specific inhibitor of airway cyclooxygenase than indomethacin. To answer this question definitively it would be necessary to perform a study comparing the effect of a single equipotent dose of each agent against sodium metabisulphite induced bronchoconstriction.

Our findings suggest that frusemide is unlikely to generate bronchoprotective prostaglandins. However, frusemide causes the renal release, not only of $\mathrm{PGE}_{2}{ }^{7}$ but also of contractile $\mathrm{PGF}_{2 x}{ }^{23}$ It is possible tht inhalation of frusemide may generate prostaglandins with opposing effects on airway smooth muscle, but we feel that this is unlikely. Both $\mathrm{PGE}_{2}$ and $\mathrm{PGF}_{2 \alpha}$ are tussive agents; ${ }^{24}$ if frusemide was generating significant airway levels of either prostaglandin it should have provoked cough, but there have been no such reports. ${ }^{1-4}$ Indeed, frusemide inhibits responses to different cough challenges ${ }^{25} 26$ providing further circumstantial evidence against a role for prostaglandins mediating its airway actions.

Flurbiprofen alone inhibited the bronchoconstrictor response to sodium metabisulphite. This effect is unlikely to result from a reduction in non-specific airway responsiveness as previous studies with this drug have failed to show an effect on histamine or methacholine induced bronchoconstriction. ${ }^{1820}$ The reduction in constrictor responses to other indirect challenges such as adenosine, allergen, and exercise ${ }^{18-20}$ has been attributed to the ability of flurbiprofen to inhibit synthesis and release of airway derived contractile prostaglandins. The inhibitory action of flurbiprofen observed in this study suggests that sodium metabisulphite stimulates the release of contractile prostaglandins from airway cells or, alternatively, that prostaglandins present in asthmatic airways may potentiate the constrictor response to sodium metabisulphite. Sodium metabisulphite does not appear to stimulate the release of histamine ${ }^{14}$ but it may activate sensory nerves. ${ }^{1315}$ Prostaglandins are neuromodulators, stimulate airway sensory nerves, ${ }^{27}$ and augment neurotransmission in efferent airway nerves. ${ }^{28}$ These observations suggest that endogenous prostaglandins may potentiate the response of asthmatic airways nerves to inhaled sodium metabisulphite and that the effects of sodium metabisulphite may partly result from the release of contractile prostaglandins.

The immediate 1.9 doubling dose protection afforded by frusemide against sodium metabisulphite is similar to that seen in our previous study. ${ }^{1}$ We have also shown that frusemide provides a small but significant 0.7 doubling dose protection against sodium metabisulphite at three hours. This is the first study to show such sustained inhibition of bronchoconstriction. Our current data and the recent observation of a reduction in the cough response to chloride-free solutions for up to and including four hours ${ }^{29}$ therefore support a prolonged airway action of frusemide.

In summary, we have shown that the protective effect of frusemide against the indirect bronchoconstrictor stimulus sodium metabisulphite is sustained for up to three hours and is unlikely to involve release of bronchoprotective prostaglandins. On the other hand, the bronchoconstrictor response to sodium metabisulphite appears to be partially mediated through the actions of cyclooxygenase products present in asthmatic airways. The precise role of contractile prostaglandins in the genesis of sodium metabisulphite induced bronchoconstriction requires further elucidation.

B J O'Connor was supported by a grant from AB Draco, Lund, Sweden, and K F Chung was supported by a grant from the Medical Research Council, UK. We thank Boots Pharmaceuticals for kindly donating flurbiprofen and matched placebos.

1 Nichol GM, Alton EW, Nix A, Geddes DM, Chung KF, Barnes PJ. Effect of inhaled frusemide on metabisulphiteBarnes PJ. Effect of inhaled frusemide on metabisulphiteand methacholine-induced bronchoconstriction and nasa potential difference in asthmatic subjects. Am Rev Respir

O'Connor BJ, Chung KF, Chen-Wordsdell YM, Fuller RW, Barnes PJ. Effect of inhaled frusemide and bumeta$\mathrm{RW}$, Barnes PJ. Effect of inhaled frusemide and bumetanide on adenosine 5'-monophosphate- and sodium metabisulphite-induced bronchoconstriction in asthmatic subjects. Am Rev Respir Dis 1991;143:1329-33.

3 Bianco S, Vaghi A, Robuschi M, Pasargiklian M. Prevention of exercise-induced bronchoconstriction by inhaled frusemide. Lancet 1988;ii:252-5.

4 Bianco S, Pieroni MG, Refini RM, Rottoli L, Sestini P Protective effect of inhaled frusemide on allergen-induced early and late asthmatic reactions. $N$ Engl $f \mathrm{Med}$ 1989;321:1069-73.

5 Robuschi M, Gamboro G, Spagnotto S, Vaghi A, Bianco S Inhaled frusemide is highly effective in preventing ultrasonically nebulised water bronchoconstriction. Pulmon Pharmacol 1989;1:187-91.

6 Mackay IG, Muir AL, Watson ML. Contribution of prostaglandins to the systemic and renal vascular response to frusemide in normal man. Br $¥$ Clin Pharmacol 1984;17:513-9. 
7 Katayama S, Attallah AA, Stahl RA, Bloch DL, Lee JB. Mechanism of frusemide-induced natriuresis by direct stimulation of renal prostaglandin $\mathrm{E}_{2} . A m \mathcal{F}$ Physiol 1984;247:F555-F561.

8 Salari H, Chan Yeung M. Release of 15-hydroxyeicosatetraenoic acid (15-HETE) and prostaglandin $\mathrm{E}_{2}$ by cultivated human bronchial epithelial cells. Am $\mathcal{F}$ Respir Cell Mol Biol 1989;1:245-50.

9 Pavord I, Wisniewski A, Mathur R, Wahedna I, Knox A, Tattersfield A. Effect of inhaled prostaglandin $E_{2}$ on bronchial reactivity to sodium metabisulphite and methacholine in subjects with asthma. Thorax 1991;46:633-7.

10 Pasargiklian $M$, Bianco $S$, Allegra L. Clinical, functional and pathogenetic aspects of bronchial reactivity to prostaglandins $\mathrm{F}_{2 x}, \mathrm{E}_{1}$, and $\mathrm{E}_{2}$. Adv Prostaglandin Thromboxane Leukotrienc Res 1976;1:461-75.

11 Pasargiklian M, Bianco S, Allegra L, Moauero NE, Petrigni $\mathrm{G}$, Robuschi $\mathrm{M}$, et al. Aspects of bronchial reactivity to prostaglandins and aspirin in asthmatic patients. Respiration 1977;34:78-91.

12 Nichol GM, Nix A, Chung KF, Barnes PJ. Characterisation of bronchoconstrictor responses to sodium metabisulphite aerosol in atopic subjects with and without asthma. Thorax 1989;44:1009-14.

13 Wright W, Zhang YG, Salome CM, Woolcock AJ. Effect of inhaled preservatives on asthmatic subjects. I. Sodium metabisulphite. Am Rev Respir Dis 1990;141:1400-4.

14 Dixon CMS, Ind PW. Metabisulphite-induced bronchoconstriction: mechanisms. Am Rev Respir Dis 1988;137:A238.

15 Dixon CMS, Ind PW. Inhaled sodium metabisulphiteinduced bronchoconstriction: inhibition by nedocromil sodium and sodium cromoglycate. Br $₹$ Clin Pharmacol 1990;30:371-6.

16 Wilkens JH, Wilkens H, Nieger M, Duft S, Frölich JC, Fabel $\mathrm{H}$, et al. Effect of inhaled lysine acetylsalicylic acid and frusemide on exercise-induced asthma. Am Rev Respir Dis 1991;143:A548.

17 Pavord ID, Wisniewski A, Tattersfield AE. Inhaled frusemide and exercise-induced asthma. Evidence of a role for inhibitory prostanoids. Thorax 1992;47:797-800.

18 Curzen N, Rafferty P, Holgate ST. Effects of a cyclooxygenase inhibitor, flurbiprofen, and an $\mathrm{H}_{1}$ histamine receptor antagonist, terfenadine, alone and in com- bination on allergen-induced immediate bronchoconstriction in man. Thorax 1987;42:946-52.

19 Finnerty JP, Holgate ST. Evidence for the roles of histamine and prostaglandins as mediators in exercise-induced asthma: the inhibitory effect of terfenadine and flurbiprofen alone and in combination. Eur Respir f 1990;3:540-7.

20 Phillips GD, Holgate ST. The effect of oral terfenadine alone and in combination with flurbiprofen on the bronchoconstrictor response to inhaled adenosine 5'-monophosphate in non-atopic asthma. Am Rev Respir Dis phosphate in non

21 Fish JE, Ankin MG, Adkinson NFJ, Peterman VI. Indomethacin modification of immediate-type immunologic airway responses in allergic asthmatic and non-asthmatic subjects: evidence for altered arachidonic acid metabolism in asthma. Am Rev Respir Dis 1981;123:609-14.

22 Kung M, Diamond L. Adenosine-induced bronchoconstriction in human asthmatics: effects of pretreatment with indomethacin or atropine sulfate. Pulmon Pharmacol 1990;3:17-23.

23 Scherer B, Weber PC. Time-dependent change in prostaglandin excretion in response to frusemide in man. Clin Sci 1979;56:77-81.

24 Costello JF, Dunlop LS, Gardiner PJ. Characteristics of prostaglandin-induced cough in man. Br $\mathcal{F}$ Clin Pharmacol 1985;20:355-9.

25 Ventresca PG, Nichol GM, Barnes PJ, Chung KF. Inhaled frusemide inhibits cough-induced by low chloride content solutions but not by capsaicin. Am Rev Respir Dis 1990;142:143-6.

26 Stone RA, Yeo CT, Barnes PJ, Chung KF. Frusemide inhibits cough but not bronchoconstriction to prostaglandin $\mathrm{F}_{2}$ alpha in patients with asthma. Am Rev Respir Dis 1991;143:A548.

27 Coleridge HM, Coleridge JC, Roberts AM. Rapid shallow breathing evoked by selective stimulation of airway $\mathrm{C}$ fibers in dogs. F Physiol, Lond 1983;340:415-33.

28 Walters EH, O'Byrne PM, Fabbri LM, Graf PD, Holtzman MJ, Nadel JA. Control of neurotransmission by prostaglandins in canine trachealis smooth muscle. $\mathcal{f} A p p l$ Physiol 1984;57:129-34.

29 Stone RA, Barnes PJ, Chung KF. Frusemide and coughinduced by low [Cl] solution: duration of action. Eur $\mathcal{F}$ Respir Dis 1993;6:862-7. 